The outsourcing of risk: out of area placements for those diagnosed with personality disorder in the UK

Harding, Keir; Poole, Rob; Robinson, Catherine

\title{
Lancet Psychiatry
}

DOI:

https://doi.org/10.1016/S2215-0366(20)30148-6

Published: 01/09/2020

Peer reviewed version

Cyswllt i'r cyhoeddiad / Link to publication

Dyfyniad o'r fersiwn a gyhoeddwyd / Citation for published version (APA):

Harding, K., Poole, R., \& Robinson, C. (2020). The outsourcing of risk: out of area placements for those diagnosed with personality disorder in the UK. Lancet Psychiatry, 7(9), 730-731. https://doi.org/10.1016/S2215-0366(20)30148-6

\footnotetext{
Hawliau Cyffredinol / General rights

Copyright and moral rights for the publications made accessible in the public portal are retained by the authors and/or other copyright owners and it is a condition of accessing publications that users recognise and abide by the legal requirements associated with these rights.

- Users may download and print one copy of any publication from the public portal for the purpose of private study or research.

- You may not further distribute the material or use it for any profit-making activity or commercial gain

- You may freely distribute the URL identifying the publication in the public portal ?
}

Take down policy

If you believe that this document breaches copyright please contact us providing details, and we will remove access to the work immediately and investigate your claim. 


\section{Editorial: The outsourcing of risk: out of area placements for those diagnosed with personality disorder in the UK}

Out of Area (OOA)Placements occur "when a person with assessed acute mental health needs who requires inpatient care, is admitted to a unit which does not form part of the usual local network of services". ${ }^{1}$ While for many, this can mean a night in the neighbouring trust, for patients diagnosed with Borderline Personality Disorder it may mean years in a distant unit.

There is increasing concern over the general use of OOA placements, for example, from the Care Quality Commission and in media reports. "Specialist" personality disorder units are self-designated, as there are no specific quality standards or requirements ${ }^{2}$. They are locked rehabilitation units - another term with no standards applied - where people are held under the mental health act in restrictive environments. Experience suggests that these locked rehabilitation units are effectively containers for those NHS services find troubling. ${ }^{2}$ Despite their name, there are rarely any structured interventions available; the specialist element is frequently limited to the sign above the door. The consequences of being compelled to reside in such units for extended periods of time can be profound.

The CQC estimate that in total there are 3,500 people in long stay locked rehabilitation wards ${ }^{2}$ with scant published data on their demography. $50 \%$ of patients on acute psychiatric wards have a diagnosis of personality disorder ${ }^{3}$. Experience shows they are at great risk of going to locked rehabilitation. A recent study demonstrated a quarter of people in private locked rehab had a diagnosis of personality disorder ${ }^{4}$. The validity of this diagnostic construct is contested, but for this client group who have often been compelled to do traumatic things in their pasts, the restriction and physical restraint is contraindicated. ${ }^{5}$

NICE guidelines ${ }^{5}$ recommend minimal use of the Mental Health Act and a focus on collaborative working. Both are incompatible with years of detention in highly restrictive environments. We repeatedly see patients who are sent to units with a promise of specialist care. Sometimes the staff believe this, sometimes they know the reality but patients are not informed and thus cannot consent. NICE recommends a variety of therapies, but these are rarely offered, or are delivered by unqualified staff.

Dialectical Behaviour Therapy (DBT) is recommended by NICE. An intrinsic element of DBT is acceptance of some degree of risk, balanced with the patient's autonomy. ${ }^{6}$ It is impossible to reconcile this with institutional care in highly risk-averse, restrictive environments. Furthermore, inpatient treatment incurs a high cost. Placements in private specialist units last twice as long as those in $\mathrm{NHS}$ services ${ }^{7}$, costing up to $£ 250,000$ per person per year, based on the authors' experience.

It is reasonable to ask organisations and professionals why they tolerate treatment for their patients that is incompatible with good practice and is extremely expensive. People with diagnoses of borderline personality disorder are notoriously stigmatised within services ${ }^{5}$. Despite numerous polices, guidelines and research findings, services continue to act as if this client group are beyond help. Services confidently respond to psychosis, but the sight of a person without a diagnosis of psychosis or depression self-harming provokes a visceral emotional response. People who have coped by cutting for years have blades taken away. Services are pleased at keeping the patient safe by eliminating controlled self laceration whilst the patient quietly moves on to the use of ligatures. Behaviours that would go unnoticed in the community provoke control strategies in hospital that move ways of 
coping from damaging to potential lethal. Clinicians are left feeling hopeless and incapable. One strategy is to keep the patient out of services; another is to move them. Professionals distressed by the risky behaviour of patients continue to find that "whatever admission to [another] hospital might do for the patient, it would also do much for them"8.

Experience suggests that otherwise thoughtful professional meetings that incorporate patients' wishes and the principles of good practice change as soon as the possibility of risk is raised, leading to defensive and restrictive practice. According to the Independent Review of the Mental Health $\mathrm{Act}^{9}$, we as practitioners have too often stopped managing the risks to our patients, and are instead managing the risks to ourselves.

Some NHS providers don't use OOA placements; ${ }^{10}$ other options are available. Current expenditure can be used to develop evidence-based community services.

Most importantly, we as mental health professionals must address the culture of fear and blame affecting clinicians and services, and instead enable them to deliver meaningful help. This requires cultural shifts and a change in political priorities.

Spending $£ 250,000$ per person per year to ensure untoward incidents happen elsewhere may be an issue that is unique to the UK. It is not an innovation to be proud of. The cost is too much for the taxpayer and far too much for individuals whose lives are damaged.

Keir Harding BSc, MSc - Clinical Lead, Beam Consultancy

Rob Poole MB BS, FRCPsych, Professor of Social Psychiatry and Co-Director, Centre for Mental Health and Society, School of Health Sciences MB, BS, Bangor University

Catherine Robinson BA, PhD. Professor of Social Care Research and Director, Social Care and Society, University of Manchester

Declarations of Interest

Keir Harding is the CEO and Clinical Lead of Beam Consultancy which helps organizations work with clients perceived as high risk, including the avoidance of Out of Area Placements.

Rob Poole has no outside interests.

Catherine Robinson has no outside interests

1 Department of Health and Social Care Guidance Out of area placements in mental health services for adults in acute inpatient care. 2016 [accessed 5/10/19] https://www.gov.uk/government/publications/oaps-in-mental-health-servicesforadults-in-acute-inpatient-care/out-of-area-placements-in-mental-healthservicesfor-adults-in-acute-inpatient-care

2 Care Quality Commission.The state of care in mental health services 2014 to 2017. 2018 [accessed 5/02/2020] 
3 Evans S, Sethi F, Dale O, Stanton C, Sedgwick R, Doran M et al (2017) Personality disorder service provision: a review of the recent literature. Mental Health Review Journal 22(2):65-82.

4 Ryan, T., Carden, J., Higgo, R., Poole, R. and Robinson, C. (2016). An assessment of need for mental health rehabilitation amongst in-patients in a Welsh region.

Social Psychiatry and Psychiatric Epidemiology, 51(9), pp.1285-1291

5 NICE. Borderline personality disorder: recognition and management Guidance and guidelines. 2009 [accessed 1/11/17] https://www.nice.org.uk/guidance/CG78

6 Linehan M. Cognitive-behavioural treatment of borderline personality disorder. New York: Guilford Press; 1993

7 Care Quality Commission Mental health rehabilitation inpatient services. 2018 [accessed 5/101/19] https://www.cqc.org.uk/sites/default/files/20180301 mh rehabilitation briefing.pdf

8 Main T. The Ailment. British Journal of Medical Psychology 1957; 30 (3) $129-145$

9 Modernising the Mental Health Act Increasing choice, reducing compulsion - Final report of the Independent Review of the Mental Health Act 1983. 2018 [accessed 5/10/19]

https://assets.publishing.service.gov.uk/government/uploads/system/uploads/at tachment_data/file/778897/Modernising_the_Mental_Health_Act__increasing_choice_reducing_compulsion.pdf

10 Graham S, Sullivan K,Briggs L,,Goodall M, Capucinello R I. A preliminary service evaluation of a personality disorder case management service. Personality and Mental Health 2019; 13 (2) 65-74 